ORIGINAL ARTICLE

\title{
High frequency of germinal centre derivation in diffuse large $B$ cell lymphoma from Asian patients
}

\author{
A K H Shia, G-G Gan, S Jairaman, S-C Peh
}

J Clin Pathol 2005;58:962-967. doi: 10.1136/jcp.2004.022624

See end of article for authors' affiliations

.....................

Correspondence to: Professor S C Peh,

Department of Pathology, Faculty of Medicine, University of Malaya 50603 Kuala Lumpur Malaysia; pehsc@ummc. edu.my

Accepted for publication 16 February 2005

\begin{abstract}
Background: Recent reports have divided diffuse large $B$ cell lymphoma (DLBCL) into germinal centre $B$ celllike and activated $B$ cell-like subgroups with implicated differences in prognosis.

Aims: To delineate the germinal centre B cell derivation group from an Asian series of DLBCLs.

Methods: Fifty four cases were analysed by polymerase chain reaction to detect the $t(14 ; 18)$ translocation and immunohistochemistry for $\mathrm{BCL2}, \mathrm{CD} 10, \mathrm{BCL} 6$, and $\mathrm{E} 2 \mathrm{~F} 1$ expression.

Results: Eighteen of 54 cases had bcl 2 gene rearrangement, 36 of 52 expressed BCL2, 29 of 52 expressed $\mathrm{BCL6}, 20$ of 53 expressed CD10, and 18 of 53 expressed E2F1. There was a significant association between bcl2 gene rearrangement and the expression of both BCL2 and CD10. Using the minimally acceptable criteria of $\mathrm{t}(14 ; 18)$ rearrangement and/or CD10 expression, 26 of 54 cases were probably germinal centre derived, in agreement with other reports. A higher proportion of cases had $t(14 ; 18)$ translocation, suggesting that they may be derived from transformed follicular lymphomas. E2F1 positivity did not correlate with the known germinal centre markers, even though it has recently been suggested that it may be a new GC marker.

Conclusions: It may be possible to stratify patients for treatment using markers for specific lineages of $B$ cell differentiation.
\end{abstract}

$\mathrm{D}$ iffuse large B cell lymphoma (DLBCL) is a clinically and morphologically heterogeneous group of lymphomas. It constitutes approximately $30-40 \%$ of all lymphomas diagnosed in the West, and accounts for an even higher proportion in developing countries. ${ }^{2}$ Previous attempts at subclassification based on morphology failed because of unacceptable interobserver and intraobserver discrepancies. ${ }^{3}$ Hence, the new World Health Organisation classification has grouped "diffuse proliferation of large neoplastic B lymphoid cells with nuclear size equal to or exceeding normal macrophage nuclei" under the umbrella term of DLBCL. ${ }^{4}$ However, grouping biologically heterogeneous entities artificially as a single disease can result in poor understanding of prognostic factors, making it difficult to improve the survival of patients. Following recent advances in microarray technology, two subgroups-the germinal centre (GC) B cell-like and the activated B cell-like-gene expression signatures have been identified. ${ }^{5}$ The identification of these subgroups by Alizadeh et al (2000) has increased the interest in defining specific markers for each. ${ }^{5}$ However, it is expected that there will be more subgroups within DLBCL than has already been described. ${ }^{6}$

\footnotetext{
"Grouping biologically heterogeneous entities artificially as a single disease can result in poor understanding of prognostic factors, making it difficult to improve the survival of patients"
}

The $t(14 ; 18)$ chromosomal translocation is reported to occur in more than $80 \%$ of follicular lymphomas, and $7-38 \%$ of DLBCLs. ${ }^{7-9}$ Diffuse lymphomas showing this trademark translocation between the $b c l 2$ gene and the immunoglobulin heavy chain ( $\mathrm{IgH})$ locus are believed to have progressed from the more indolent follicular lymphoma. ${ }^{10}$ The translocation to the IgH promoter deregulates the bcl2 gene, causing overexpression of the protein. Most breakpoints are clustered at the $3^{\prime}$ untranslated region of exon 3, known as the major breakpoint region (MBR) of the $b c l 2$ gene. ${ }^{11}$ However, translocation of the $b c l 2$ gene does not correlate significantly with overexpression of the BCL2 protein in DLBCL. ${ }^{12}$

Both CD10 and BCL6 have been hailed as reliable GC markers. ${ }^{13}{ }^{14} \mathrm{CD} 10$ is a single chain $100 \mathrm{kDa}$ type II cell surface glycoprotein with a sequence identical to neural endopeptidase. Its expression in lymphoid cells is strictly confined to the follicles of GCs. ${ }^{15}$ The expression of CDI0 has been used to distinguish follicular lymphoma from other low grade non-Hodgkin lymphomas. ${ }^{16}$

The bcl6 gene is a newly discovered putative protooncogene that encodes the BCL6 protein, which is expressed exclusively in the follicular centre B cells of reactive lymphoid tissue..$^{15}$ It is presumed that translocation of the bcl6 gene, found in $30-40 \%$ of DLBCLs, upregulates the protein by virtue of promoter substitution. ${ }^{10}$ Mutations at the $5^{\prime}$ non-coding region of the gene are also thought to play a role in regulating the expression of the protein. ${ }^{18}$ A recently elucidated mechanism proposes that the BCL6 protein is negatively autoregulated under normal circumstances, so that mutations in the autoregulatory region would lead to increased protein expression. ${ }^{19}$ It is possible that overexpression of BCL6 inhibits the terminal differentiation of GC B cells, and facilitates the transformation of cells. ${ }^{19}$

It has been proposed that expression of both CDI0 and BCL6 be used to determine the GC derivation of tumour cells. ${ }^{13}{ }^{14}$ CDIO and BCL6 have been reported as markers of both improved survival and adverse prognosis. ${ }^{20-22}$ However, recent studies noted that these proteins are associated with GC derived DLBCL, implying an association with improved survival. ${ }^{56}$

The transcription factor E2Fl is one of a group of proteins that mediate cell cycle progression from the Gl to $S$ phase. ${ }^{23}$

Abbreviations: DLBCL, diffuse large $B$ cell lymphoma; GC, germinal centre; lgH, immunoglobulin heavy chain; $\mathrm{JH}$, joining region; MBR, major breakpoint region; $M C R$, minor cluster region; $P C R$, polymerase chain reaction 
In resting cells, E2F1 is sequestered by being bound to the hypophosphorylated retinoblastoma protein. When the retinoblastoma protein is phosphorylated, E2Fl protein is freed and becomes biologically active. Active E2Fl, bound to its partner DP1, is then able to bind to the promoter regions of genes involved in DNA synthesis, such as those encoding cyclin E, cyclin A, cdc2, cyclin dependent kinase 2, thymidine kinase, and DNA polymerase $\alpha$, and promote cell cycle progression. It is thought that the protein is the ultimate effector of Gl to S cycle progression. Study into the function of this protein is relatively new, and the pattern of staining has only recently been described. ${ }^{24}$ Hence, its possible role in lymphomagenesis needs further investigation and evaluation.

In a previous study of a series of Asian adult non-Hodgkin lymphomas from a single medical centre, DLBCL was found to constitute a large proportion (58\%) of the cases. ${ }^{2}$ Therefore, it is important to gain a better understanding of this group of tumours and be able to delineate tumours with GC properties from other subtypes.

\section{MATERIAL AND METHODS}

Patients' material

Cases diagnosed as DLBCL from four consecutive years (1996-1999) were retrieved from the archives of the department of pathology, University of Malaya Medical Centre, Malaysia for our study. These cases were reviewed and reconfirmed as DLBCL according to the criteria of the new World Health Organisation classification. Cases with insufficient material, missing blocks, or with a doubtful diagnosis after the review were excluded from further analysis. In total, 54 cases were included in our study. The patients' demographic data were obtained from the pathology request forms provided by the supervising clinician.

\section{Immunohistochemical stain}

Serial $4 \mu \mathrm{m}$ thick sections were mounted on silanised slides, dewaxed in xylene, and cleared in alcohol, followed by a microwave or pressure cooking antigen retrieval step. Staining was performed according to a standard three step immunoperoxidase method. Table 1 summarises the panel of antibodies used and the methods applied for the respective antibodies. Semiquantitative evaluation of expression was performed by a pathologist (SCP). The tumour was considered to be BCL2 or CD10 positive if more than $75 \%$ of the tumour cells were positive, whereas for BCL6 and E2Fl this figure was $10 \%$. Reactive lymphoid tissues were used as positive controls for the staining procedure. The cutoff points for the different stains were established from background staining of hyperplastic lymphoid tissue to determine overexpression resulting from the tumour.

\section{PCR detection of $t(14 ; 18)$ translocation}

DNA was extracted from formalin fixed, paraffin wax embedded tissues using proteinase $\mathrm{K}(200 \mu \mathrm{g} / \mathrm{ml})$ digestion
Table 2 Sequence of primers used for nested PCR amplification of $M B R / J H$ and $M C R / J H$

\begin{tabular}{ll}
\hline Chromosome regions & Primer sequence \\
\hline IGH JH external & 5' ACC TGA GGA GAC GGT GAC 3' \\
IGH JH internal & 5' ACC AGG GTC CCT TGG CCC CA 3' \\
bcl2 MBR external & 5' CAG CCT TGA AAC ATT GAT GG 3' \\
bc/2 MBR internal & 5' TAT GGT GGT TTG ACC TIT AG 3' \\
bc/2 MCR external & 5' CGT GCT GGT ACC ACT CCT G 3' \\
bc/2 MCR internal & 5' GGA CCT TCC TTG GTG TGT TG 3'
\end{tabular}

$I G H$, immunoglobulin heavy chain gene; JH, J region; MBR, major breakpoint region; $M C R$, minor cluster region; PCR, polymerase chain reaction.

as described by Zhang et al. ${ }^{25}$ The supernatant containing DNA was used directly for polymerase chain reaction (PCR) amplification. A nested PCR method previously described by Gribben et al was used to amplify the MBR and minor cluster region (MCR) of the $b c l 2$ gene. ${ }^{26}$ PCR was performed in a final volume of $50 \mu \mathrm{l}$ using $5 \mu \mathrm{l}$ of the template DNA, $0.5 \mu \mathrm{M}$ of oligonucleotide primers (table 2), $0.4 \mathrm{mM}$ of each dNTP (dATP, dGTP, dCTP, dTTP) (Fermentas, Vilnius, Lithuania), 3.0mM magnesium chloride, $2.0 \mathrm{U}$ HotStarTaq DNA polymerase (Qiagen, Hilden, Germany), and $1 \times$ PCR buffer (Qiagen). The initial PCR amplification was performed with 15 minutes of preheating at $95^{\circ} \mathrm{C}$ to activate the HotStarTaq DNA polymerase, followed by 30 cycles of one minute of denaturation at $95^{\circ} \mathrm{C}$, one minute of annealing at $55^{\circ} \mathrm{C}$ for MBR or $58^{\circ} \mathrm{C}$ for MCR, and one minute of extension at $72^{\circ} \mathrm{C}$. After 30 cycles, the samples were incubated for a final extension step at $72{ }^{\circ} \mathrm{C}$ for two minutes to complete the reaction. Nested PCR using $5 \mu \mathrm{l}$ aliquots of the first PCR reaction product was performed for 30 cycles using primers internal to the first primer set (table 2). The same cycling conditions as in the first PCR were used for the nested PCR. Contamination was tested by incorporating negative controls without DNA template for both the first and nested PCR reactions. The size of the products ranged from 100 to $300 \mathrm{bp}$ for $\mathrm{MBR} / \mathrm{JH}$ and 500 to $1000 \mathrm{bp}$ for $\mathrm{MCR} / \mathrm{JH}$ rearrangement. Cell lines RL-7 and SU-DHL-16 (provided by Dr J W Chan, University of Nebraska Medical Centre, USA) were used as positive controls for MBR and MCR, respectively. The products were separated on a $2 \%$ agarose gel (Hispanlab, Alcobendas, Spain) containing $5 \mu \mathrm{g} / \mathrm{ml}$ ethidium bromide (Gibco BRL, Gaithersburg, Maryland, USA) and visualised on an ultraviolet illuminator.

\section{Criteria for GC derivation}

Cases were considered to be GC derived if they showed minimally acceptable criteria of $b c l 2$ translocation or CD10 expression. These criteria were determined based on the reports of Huang et al and McCluggage et al, who found bcl2 translocated cases to represent a subset of GC derived cases,

Table 1 Antibodies, sources, clones, antigen retrieval methods, dilutions, and detection methods used

\begin{tabular}{|c|c|c|c|c|c|}
\hline Antibody & Source & Clone & Antigen retrieval & Dilution & Detection \\
\hline CD20 & Dako, Glostrup, Denmark & L26; monoclonal & $\mathrm{MW}, \mathrm{CB}$ pH 6.0 & $1 / 500$ & $A B C$ \\
\hline CD3 & Dako & CD3; polyclonal & $\mathrm{MW}, \mathrm{CB}$ pH 6.0 & $1 / 100$ & $A B C$ \\
\hline BCL6 & Dako & PG-B6p; monoclonal & PC, EDTA pH 8.0 & $1 / 25$ & StreptABC \\
\hline $\mathrm{BCL} 2$ & Dako & 124; monoclonal & $\mathrm{MW}, \mathrm{CB}$ pH 6.0 & $1 / 50$ & Envision \\
\hline CD10 & Novocastra, Newcastle, UK & NCL-CD10-270; monoclonal & $\begin{array}{l}\text { MW, Dako high pH retrieval } \\
\text { solution }\end{array}$ & $1 / 50$ & Envision \\
\hline $\mathrm{E} 2 \mathrm{~F} 1$ & $\begin{array}{l}\text { Santa Cruz Technology, Santa Cruz, } \\
\text { California, USA }\end{array}$ & KH95; monoclonal & MW, EDTA pH 8.0 & $1 / 20$ & StreptABC \\
\hline
\end{tabular}

$A B C$, avidin-biotin complex; $C B$, citrate buffer; Envision, Dako EnVision $+{ }^{T M}$ mouse peroxidase; EDTA, $0.1 \mathrm{mM}$ EDTA; MW, microwave; PC, pressure cooker; StrepABC, streptavidin-biotin complex. 


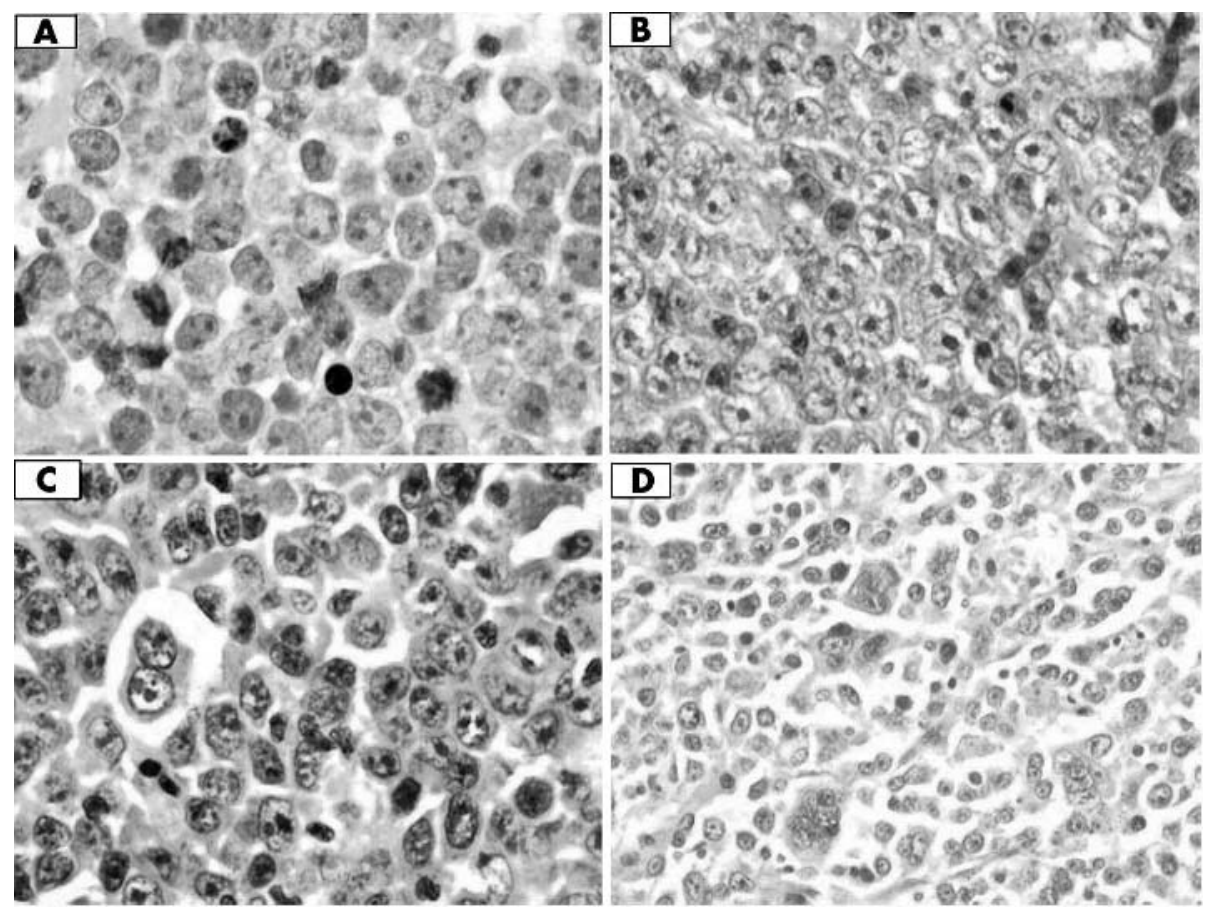

Figure 1 Haematoxylin and eosin stains showing the wide range of pleomorphism in our cases of diffuse large B cell lymphoma; original magnification, $\times 600$. (A) Centroblastic morphology, (B) immunoblastic morphology, (C) plasmablastic morphology, and (D) polylobated cells.

and CDI0 to be a more specific marker for their groups of GC derived tumours when compared with BCL6. ${ }^{27} 28$

\section{Statistical analysis}

Statistical analysis for immunophenotype was carried out using the $\chi^{2}$ test and SPSS version 10.0 software. A p value of less than 0.05 was considered significant.

\section{RESULTS}

\section{Demography}

There were 33 male and 21 female patients, with a male to female ratio of $1.6: 1$. There were 27 Chinese, 22 Malays, and five Indians. The ages of the patients ranged from 9 to 86 years, with a mean of 49 , and a median of 52 . Of the 54 cases, there were 11 with extranodal presentation. The extranodal sites were the testicles (three), retroperitoneum (one), small bowel (one), and the soft tissue of the thigh (one), bone (one), skin (two), rectum (one), and nose (one).

\section{Morphological appearance}

All cases were composed of large lymphoid cells of B cell phenotype, with vesicular and hyperchromatic nuclei, prominent nucleoli, and varying amounts of cytoplasm. The cellular morphology was heterogeneous, with some being centroblast-like, others immunoblastic or mixed, and still others with a range of pleomorphism of nuclear sizes including multinucleation (fig 1 ).

\section{Immunophenotypic expression}

Figure 2 shows the staining pattern for each antibody. The staining patterns of CD10, BCL6, and BCL2 agreed with previous reports, but E2Fl showed stronger nuclear membrane staining in our series. Some of these cases were either non-reactive or showed non-specific staining, and they were excluded from further analysis. These involved two cases each for BCL6 and BCL2, and one each for CD10 and E2F1 staining. Of the well stained cases, 29 of 52 showed positive BCL6 expression, 20 of 53 expressed CD10, 36 of 52 expressed
BCL2, and 18 of 53 expressed E2F1. The expression of these proteins was not significantly associated with one another.

\section{$B c / 2$ gene rearrangement}

Molecular analysis for bcl2 rearrangement was performed in all cases. Figure 3 shows the positive bands in the PCR analysis. Eighteen of 54 cases showed rearrangement involving $\mathrm{MBR} / \mathrm{JH}$, but none showed $\mathrm{MCR} / \mathrm{JH}$ rearrangents. There was a significantly association between $b c l 2$ gene rearrangement and CD10 expression $(\mathrm{p}=0.018)$, and also between bcl2 gene rearrangement and BCL2 protein expression $(\mathrm{p}=0.039$; table 3$)$. However, only 15 of 36 BCL2 expressing cases showed $b c l 2$ gene rearrangement.

These cases were subclassified into eight groups according to the presence or absence of $b c l 2$ gene rearrangement and the expression status of CD10 and BCL6 (table 4). Using the GC defining criteria already described, 26 of the 54 cases showed a GC derivation.

\section{DISCUSSION}

Recent data that subgrouped DLBCL into GC B-like DLBCL and activated B-like DLBCL, showed that GC-like DLBCL had a much better overall survival, at $76 \%$ and $16 \%$, respectively, after five years. ${ }^{5}$ This increased interest in studying follicular centre cell markers to determine GC derivation within the heterogeneous group of DLBCLs. Studies have shown that CD10, BCL6, and BCL2 expression and $t(14 ; 18)$ rearrangement are reliable characteristics of follicular centre cell lymphomas ${ }^{913}$; in addition, a recent report implicated E2Fl as a prognostic marker. ${ }^{29}$

About a third of our series of DLBCLs showed bcl2 gene rearrangements (table 3 ), which falls within the reported range of $7-38 \% .^{7-9} 30$ We were unable to detect MCR rearrangements; this could partially be explained by the large PCR product ( $>600 \mathrm{bp}$ ), because amplification of larger products is difficult using paraffin wax embedded sections. The rate of expression of BCL2 (36 of 52; 69\%; table 3) also agrees with the reported range of $40-81 \% .^{7930}$ 


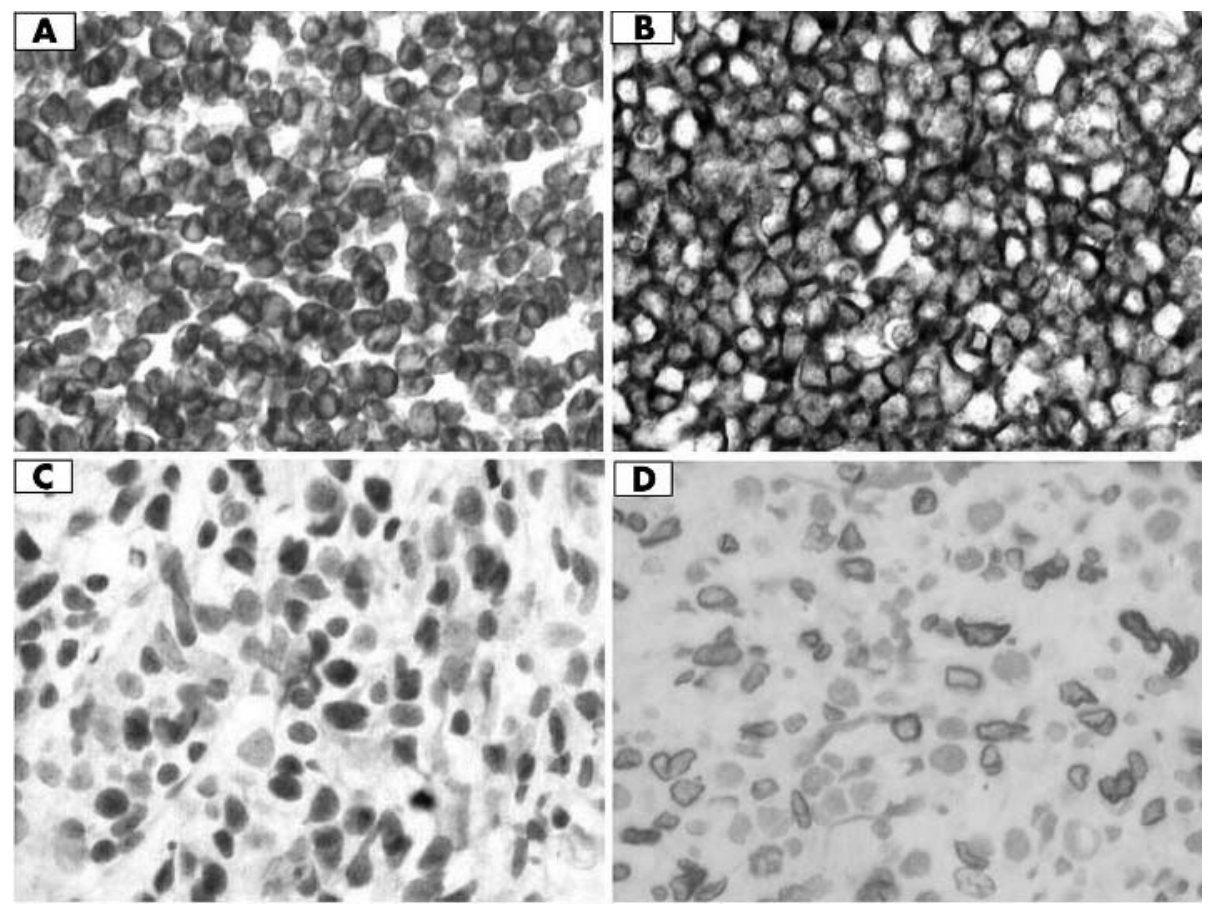

Figure 2 Immunohistochemical staining of diffuse large B cell lymphoma; original magnification, $\times 600$. (A) BCL2 expression, (B) CD10 expression, (C) BCL6 expression, and (D) E2F1 expression.

Although $\mathrm{t}(14 ; 18)$ translocation was found to be significantly associated with BCL2 protein expression, it has often been reported that protein expression is independent of gene rearrangement. ${ }^{78}$ This was supported by the $t(14 ; 18)$ translocation being present in only a proportion (15 of 36) of BCL2 positive DLBCL cases. Hence, a large number of BCL2 expressing cases $(21 / 36)$ do not have the $t(14 ; 18)$ translocation, which agrees with the hypothesis that other genetic alterations may be involved in upregulation of the gene. ${ }^{31}$ Rantanen et al suggested that gene amplification may be more important than gene rearrangement for BCL2 overexpression. $^{32}$

With only 29 of $52(58 \%)$ of our series expressing BCL6, this falls within the lower end of the reported range of 57-95\%. ${ }^{91}$ Although it has been reported that long exposure of cut sections to air, old blocks, or imperfect fixation could affect BCL6 staining, ${ }^{31}$ the lack of BCL6 expression could also result from $b c l 6$ gene rearrangements or somatic hypermutation at the $5^{\prime}$ non-coding region. ${ }^{183}$ It is possible that

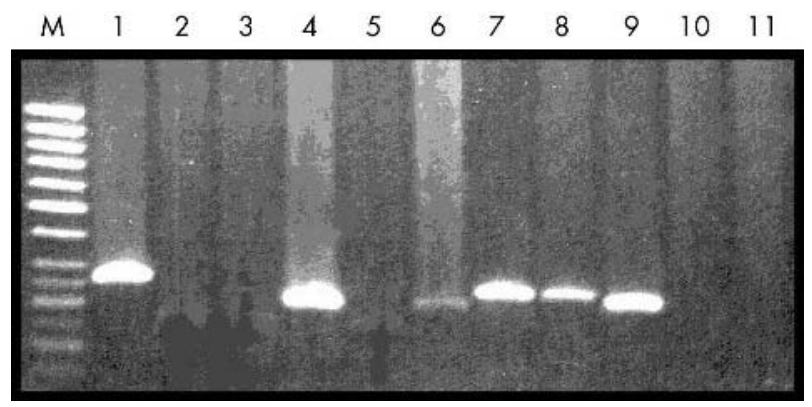

Figure 3 Polymerase chain reaction (PCR) amplification product bands of the major breakpoint region/joining region in diffuse large B cell lymphoma (DLBCL). M, 50 bp DNA marker; lane 1, positive control (RL7; $275 \mathrm{bp})$, lanes 2,3 , and $5, t(14 ; 18)$ translocation negative DLBCL cases; lanes $4,6,7,8,+(14 ; 18)$ translocation positive DLBCL cases; lanes 10,11 , first and second PCR negative controls. deregulation of BCL6 in the GC may result in the perturbation of proteins that control apoptosis, and the subsequent loss of control could lead to cells continually proliferating outside of the GC. In this way, the behaviour of cells overexpressing BCL6 is analogous to that of those overexpressing BCL2.

"We speculate that the lower frequency of follicular lymphoma detected in the Asian population may result from early transformation of follicular lymphoma to diffuse large B cell lymphoma"

E2F1 staining was present in 18 of 53 (34\%) of our cases, lower than previous reports of $43-83 \% .^{24}{ }^{29}{ }^{34}$ It was included in the study as a possible new GC marker. However, it showed no significant association with other known GC markers. It is possible that in DLBCL the E2F1 protein may be lost or mutated, leading to a lower detection rate. Moller et al found that low expression of the E2Fl protein is related to treatment failure in DLBCL. ${ }^{29}$ The E2Fl protein has both oncogenic and tumour suppressive abilities; too much or too

Table 3 The series of diffuse large B cell lymphomas showing bcl2 gene rearrangement and their immunophenotypic expression

\begin{tabular}{|c|c|c|c|c|}
\hline & & \multicolumn{2}{|c|}{$t(14 ; 18)$ translocation } & \multirow[b]{2}{*}{$\mathrm{p}$ Value } \\
\hline & & + & - & \\
\hline \multirow[t]{2}{*}{$\mathrm{BCL} 2$} & + & 15 & 21 & 0.039 \\
\hline & - & 2 & 14 & \\
\hline \multirow[t]{2}{*}{ CD10 } & + & 12 & 8 & 0.018 \\
\hline & - & 6 & 27 & \\
\hline \multirow[t]{2}{*}{ E2F1 } & + & 6 & 12 & 0.597 \\
\hline & - & 12 & 23 & \\
\hline \multirow[t]{2}{*}{ BCL6 } & + & 11 & 18 & 0.395 \\
\hline & - & 7 & 16 & \\
\hline
\end{tabular}


Table 4 Subclassification of our cohort of diffuse large B cell lymphomas

\begin{tabular}{|c|c|c|}
\hline Group & Immunophenotype & No. \\
\hline I & $+(14 ; 18)+$, BCL6+, CD10+ & 7 \\
\hline ॥ & $\mathrm{t}(14 ; 18)+, \mathrm{BCL} 6+, \mathrm{CD} 10-$ & 5 \\
\hline III & $\mathrm{t}(14 ; 18)+, \mathrm{BCL} 6-, \mathrm{CD} 10+$ & 4 \\
\hline IV & $\mathrm{H}(14 ; 18)+, \mathrm{BCL6}-, \mathrm{CD} 10-$ & 2 \\
\hline $\mathrm{V}$ & $+(14 ; 18)-$, BCL6+, CD10+ & 7 \\
\hline VI & $\mathrm{t}(14 ; 18)-, \mathrm{BCL} 6-, \mathrm{CD} 10+$ & 1 \\
\hline VII & $\mathrm{t}(14 ; 18)-, \mathrm{BCL} 6+, \mathrm{CD} 10-$ & 11 \\
\hline VIII & $+(14 ; 18)-$, BCL6-, CDI0- & 17 \\
\hline
\end{tabular}

little E2F1 protein can induce apoptosis. ${ }^{23}$ Because the role of E2Fl appears to be cell type dependent, more data on the role of E2Fl in lymphoma cells are needed to confirm the hypothesis by Moller et al that E2FI is a tumour suppressor gene. $^{29}$

Our study suggested that 26 of 52 of our DLBCL cases could be GC derived. This finding agrees with Alizadeh et al and McCluggage et al, who found that 21 of 42 and 15 of 34 of their cases were GC derived, respectively. ${ }^{55}$ We considered groups I-IV to be transformed from follicular lymphoma because they show the characteristic $b c l 2$ gene rearrangement, ${ }^{11}$ and the $t(14 ; 18)$ translocation has been detected only at a very low frequency in benign hyperplastic lymph nodes and blood samples from normal donors, whereas this translocation is mostly restricted to follicular lymphoma and cases of DLBCL transformed from follicular lymphoma, and has not been detected in other lymphomas. ${ }^{11}$ Bcl2 gene rearrangements in other lymphomas often involve variant translocations. Hence, we conclude that we have a higher proportion ( 18 of $26 ; 69 \%$ ) of cases that appear to have been transformed from follicular lymphoma compared with the series of Huang et al (seven of 20;35\%) and McCluggage et al (five of $15 ; 33 \%$ ). We speculate that the lower frequency of follicular lymphoma detected in the Asian population may result from early transformation of follicular lymphoma to DLBCL.

The concept that the neoplastic cell will continue to express markers of its biological origin, and that these markers can therefore be used to define disease entities and predict the clinical outcome, is relatively new. Some markers may be more helpful than others in predicting the clinical outcome of

\section{Take home messages}

- There was a significant association between $b c / 2$ gene rearrangement and expression of both $\mathrm{BCL} 2$ and CD10 in our series of diffuse large B cell lymphomas (DLBCLs) from Asian patients

- Using the minimally acceptable criteria of $t(14 ; 18)$ rearrangement and/or CD10 expression, 26 of 54 cases were classed as germinal centre derived, a similar proportion to that reported previously

- A higher proportion of cases had $t(14 ; 18)$ translocation, suggesting that they may be derived from transformed follicular lymphomas

- E2F1 positivity did not correlate with known germinal centre markers, so that this marker may not be specific for germinal centre derived DLBCLs

- It may be possible to stratify patients for treatment using markers for specific lineages of B cell differentiation patients and, in the future, some of these biological markers might be used routinely to assist in the management of patients.

\section{ACKNOWLEDGEMENTS}

This study was supported by a grant (Top-Down Biotechnology, 2602-03-0586) from the Ministry of Science, Technology, and the Environment, Malaysia. Thanks to Dr W Chan for providing positive DNA controls for $\mathrm{t}(14 ; 18)$ translocation and to Dr RK Brynes for his assistance in E2Fl immunohistochemistry.

\section{Authors' affiliations}

A K H Shia, G-G Gan, S Jairaman, S-C Peh, Department of Pathology, Faculty of Medicine, University of Malaya, 50603 Kuala Lumpur, Malaysia

\section{REFERENCES}

1 Anderson JR, Armitage JO, Weisenburger DD. Epidemiology of the nonHodgkin's lymphomas: distributions of the major subtypes differ by geographic locations. Ann Oncol 1998;9:717-20.

2 Peh SC. Host ethnicity influences non-Hodgkin's lymphoma (NHL) subtype frequency and Epstein-Barr virus association rate: the experience of a multiethnic population in Malaysia. Histopathology $2001 ; 38: 456-8$.

3 Harris NL, Jaffe ES, Stein $\mathrm{H}$, et al. A revised European-American classification of lymphoid neoplasms: a proposal from the international lymphoma study group. Blood 1994;84:1361-92.

4 Gatter KC, Warnke RA. Diffuse large B-cell lymphoma. In: Jaffe ES, Harris NL, Stein $\mathrm{H}$, et al, eds. World Health Organization classification of tumours, pathology and genetics of tumours of haematopoietic and lymphoid tissue. Lyon: IARC Press, 2001:171-4.

5 Alizadeh AA, Eisen MB, Davis ER, et al. Distinct types of diffuse large B-cell lymphoma identified by gene expression profiling. Nature 2000;403:503-11.

6 Rosenwald A, Wright G, Chan WC, et al. The use of molecular profiling to predict survival after chemotherapy for diffuse large-B-cell lymphoma. N Engl J Med 2002;346:1937-47.

7 Hill ME, MacLennan KA, Cunningham DC, et al. Prognostic significance of $\mathrm{BCL}-2$ expression and bcl-2 major breakpoint rearrangement in diffuse large cell non-Hodgkin's lymphoma: a British national lymphoma investigation study. Blood 1996;88:1046-51.

8 Gascoyne RD, Adomat SA, Krajewski S, et al. Prognostic significance of Bcl-2 protein expression and $\mathrm{BCl}-2$ gene rearrangement in diffuse aggressive nonHodgkin's lymphoma. Blood 1997;90:244-51.

9 King BE, Chen C, Locker J, et al. Immunophenotypic and genotypic markers of follicular center cell neoplasia in diffuse large B-cell lymphomas. Mod Pathol 2000;13:1219-31.

10 Dalla-Favera $\mathbf{R}, \mathrm{Ye}$ BH, Lo Coco F, et al. Identification of genetic lesions associated with diffuse large-cell lymphoma. Ann Oncol 1994;5:S55-60.

11 Meijerink PP. t(14;18), a journey to eternity. Leukemia 1997;11:2175-87.

12 Pezzella F, Tse AG, Cordell JL, et al. Expression of the bcl-2 oncogene protein is not specific for the 14;18 chromosomal translocation. Am J Pathol 1990; 137:225-32.

13 Barrans SL, Carter I, Owen RG, et al. Germinal center phenotype and bcl-2 expression combined with the international prognostic index improves patient risk stratification in diffuse large B-cell lymphoma. Blood 2002;99:1136-43.

14 Ree HJ, Yang WI, Kim CW, et al. Coexpression of Bcl-6 and CD10 in diffuse large B-cell lymphomas: significance of $\mathrm{BCl}-6$ expression patterns in identifying germinal center B-cell lymphoma. Hum Pathol 2001;32:954-62.

15 Dogan A, Bagdi E, Munson P, et al. CD10 and BCL-6 expression in paraffin sections of normal lymphoid tissue and B-cell lymphomas. Am J Surg Pathol 2000;24:846-52.

16 Almasri NM, Iturraspe JA, Braylan RC. CD10 expression in follicular lymphoma and large cell lymphoma is different from that of reactive lymph node follicles. Arch Pathol Lab Med 1998;122:539-44.

17 Pittaluga S, Ayoubi TAY, Wlodarska I, et al. BCL-6 expression in reactive lymphoid tissue and in B-cell non-Hodgkin's lymphomas. J Pathol 1996;179:145-50.

18 Migliazza A, Martinotti S, Chen W, et al. Frequent somatic hypermutation of the $5^{\prime}$ noncoding region of the BCL6 gene in B-cell lymphoma. Proc Natl Acad Sci U S A 1995;92:12520-4.

19 Wang X, Li Z, Naganuma A, et al. Negative autoregulation of BCL-6 is bypassed by genetic alterations in diffuse large $B$ cell lymphomas. Proc Natl Acad Sci U S A 2002;99:15018-23.

20 Xu Y, McKenna RW, Molberg KH, et al. Clinicopathologic analysis of CD10+ and CD10-diffuse large B-cell lymphoma. Am J Clin Pathol $2001 ; 116: 183-90$.

21 Lossos IS, Jones CD, Warnke R, et al. Expression of a single gene, BCL-6, strongly predicts survival in patients with diffuse large B-cell lymphoma. Blood 2001;98:945-51.

22 Ohshima K, Kawasaki C, Muta K, et al. CD10 and Bcl10 expression in diffuse large B-cell lymphoma: CD10 is a marker for improved prognosis. Histopathology 2001;39:156-62

23 Dyson N. The regulation of E2F by pRb-family proteins. Genes Dev 1998; 12:2245-62. 
24 Lai R, Medeiros $\sqcup$, Coupland R, et al. Immunohistochemical detection of E2F-1 in non-Hodgkin's lymphomas: a survey of 124 cases. Mod Pathol 1998;11:457-63.

25 Zhang DX. Isolation of DNA from preserved specimens. In: Isaacson PG, Ingram DS, eds. Molecular tools for screening biodiversity 1998:41-5.

26 Gribben JG, Freedman A, Woo SD, et al. All advanced stage non-Hodgkin's lymphomas with a polymerase chain reaction amplifiable breakpoint of bcl-2 have residual cells containing a bcl-2 rearrangement at evaluation and after treatment. Blood 1991;78:3275-80.

27 Huang JZ, Sanger WG, Greiner RC, et al. The $t(14 ; 18)$ defines a unique subset of diffuse large B-cell lymphoma with a germinal center B-cell gene expression profile. Blood 2002;99:2285-90.

28 McCluggage WG, Catherwood M, Alexander HD, et al. Immunohistochemical expression of CD10 and $+(14 ; 18)$ chromosomal translocation may be indicators of follicle centre origin in nodal diffuse large B-cell lymphoma. Histopathology 2002;41:414-20.

29 Moller MB, Kania PW, Ino Y, et al. Frequent disruption of the RB1 pathway in diffuse large $B$ cell lymphoma: prognostic significance of E2F-1 and pl6INK4A. Leukemia 2000;14:898-904.
30 Kramer MHH, Hermans J, Wijburg E, et al. Clinical relevance of BCL2, BCL6, and MYC rearrangements in diffuse large B-cell lymphoma. Blood 1998;92:3152-62

31 Skinnider BF, Horsman DE, Dupuis D, et al. $\mathrm{Bcl}-6$ and $\mathrm{Bcl}-2$ protein expression in diffuse large B-cell lymphoma and follicular lymphoma: correlation with $3 q 27$ and 18q21 chromosomal abnormalities. Hum Pathol 1999:30:803-8.

32 Rantanen S, Monni O, Joensuu $\mathrm{H}$, et al. Causes and consequences of BCL2 overexpression in diffuse large B-cell lymphoma. Leuk Lymphoma 2001;42:1089-98

33 Barrans SL, O'Connor SJM, Evans PAS, et al. Rearrangement of the BCL6 locus at 3q27 is an independent poor prognostic factor in nodal diffuse large B-cell lymphoma. Br J Haematol 2002; 117:322-32.

34 Chan JA, Olvera M, Lai R, et al. Immunohistochemical expression of the transcription factor DP-1 and its heterodimeric partner E2F-1 in nonHodgkin's lymphoma. Appl Immunohistochem Mol Morphol 2002;10:322-6.

35 McCluggage WG, Catherwood M, Alexander HD, et al. Immunohistochemical expression of $C D 10$ and $t(14 ; 18)$ chromosomal translocation may be indicators of follicle centre origin in nodal diffuse large B-cell lymphoma. Histopathology 2002;41:414-20.

\section{$\mathrm{ECHO}$}

\section{Rules on organ donation are coherent}

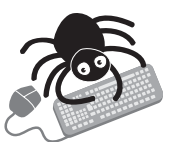

Please visit the Journal of Clinical Pathology website [www. jclinpath.com] for a link to the full text of this article.
D ules about consent to organ donation are being reviewed in the United Kingdom and Dew Zealand. In law, organs and tissues cannot be taken after death if the deceased have not consented. Medical practice is also not to proceed if a family refuses consent, even against the wishes of the dead donor. These arrangements-the so called double vetomay be right or wrong but at least they are coherent, and that is encouraging, says one commentator.

The ethical situation is complex: arguments for granting a veto to one side tend to undermine those for the granting it to the other. The double veto can be interpreted as coherent by adopting an argument that it has the best effects, or an alternative argument that the rights of the deceased and their families are negative rights - against interferenceas opposed to positive rights-to obtaining help-and therefore limited to a veto.

The best effects argument contends that once all costs and benefits are taken into account, including the supply of organs or tissues, effect on recipients, their families, and the dead person, even extending to effects on medical care, a veto over consent leads to greatest net benefit. Showing this needs empirical research.

The argument based on rights - in the sense of moral claims that cannot be overriddenholds that if deceased and their families have only negative rights the double veto has the beginnings of a coherent plan. This scenario seems unlikely to our commentator; instead, he argues that consent from donors or families does not impose a correlative duty on doctors to comply.

A Wilkinson TM. Journal of Medical Ethics 2005;31:00-00. 